\title{
THE ANALYSIS OF SUNDANESE LANGUAGE TO STUDENTS' ENGLISH CONSONANT PRONUNCIATION CONDUCTED IN SMA MUTIARA PALABUHANRATU
}

\author{
$1^{\text {st }}$ Anisa Alawiyyah \\ English Education Program \\ STKIP Bina Mutiara Sukabumi, Indonesia \\ nisaalawi@gmail.com
}

\author{
$2^{\text {nd }}$ Handi Pabriana \\ English Education Program \\ STKIP Bina Mutiara Sukabumi, Indonesia \\ handypabriana109@gmail.com
}

\begin{abstract}
The aims of the research is to know the main appearances of students English consonant, pronunciation, fricative English sounds pronounced by Sundanese student, and new variant appeared in student English consonant. This research used descriptive qualitative as the method. The instruments used are questionnaire, test and interview which be held to 42 samples of SMA Mutiara Terpadu. Research result found that $100 \%$ sample transformed the sound $ð$ to $\mathrm{d}$ or $\mathrm{t}, 100 \%$ sample transformed the sound ' 3 ' to ' $s$ ', $100 \%$ sample transformed ' $f$ ' to ' $c$ ', $96 \%$ sample transformed 'ds' to 'd' or ' $\mathrm{g}$ ', $98 \%$ sample transformed ' $\mathrm{f}$ ' to 's', $94 \%$ samples transformed 'f' to 'p', 100\% samples transformed ' $v$ ' to 'f' or 'p', 100\% samples transformed ' $\theta$ ' to ' $t$ ', and $100 \%$ samples transformed ' $z$ ' to ' $\mathrm{s}$ ' to ' $\mathrm{j}$ '. The double consonant in a word was banned, such as 'around' to 'aroun'. The conclusion is the unknown consonant of Sundanese in English transformed to Sundanese similar sound, and the rule of English pronunciation was equal to Sundanese rules.
\end{abstract}

Keywords: sundanese language; english consonant; pronunciation

\section{INTRODUCTION}

In this modern era, we are forced to be able to communicate with people around the world. Communication related with the language that every country has their language. English as most spoken English in the world made it become an international language. Learning English as foreigner language has many problems especially with their mother tongue. Even though in Indonesia, English is important subject to learn. In that position Indonesia is as a multicultural country, with 1430 tribes spread on every island. More than 746 regional languages used by many Indonesian especially Sundanese. The third biggest language in Indonesia, more than 43 million people use Sundanese as a language for communicating.
Sundanese spread in West Java and the transmigration area such as Lampung, Kalimantan, and other. The majority of Sundanese live in West Java, the most densely populated in Indonesia. For sure many of Sundanese learn English as a way for communicating with another country. The relation of both languages is influence each other especially English. For sure Sundanese as the second most spoken language in Indonesia. Many Sundanese native learnt English especially students. The different structure both of language was influence especially the different of consonant.

According to Sudaryat (2013) Sundanese language is mother tongue for Sundanese in West Java who lived in West Java and other region in Indonesia. The amount of Sundanese native 
language was a big, it made Sundanese as the second of the biggest region language after Javanese. Before the independence of Indonesia, Sundanese was a first language in West Java. The use of kind Sundanese language in region was long time mentioned as Sundanese regional language. It can be analized from vocabulary, accent and intonation. According to PPPB the center of guiding and language conservation written by Suriamiharja (1981), there are Sumedang, Cianjur, Ciamist, Serang, Cianjur, Subang, Tasikmala, and Purwakarta dialect. Beside those, there is a personal local dialect such as dialect of Cirebon (Ayatrohede, 1978 stated in Sudaryat, 2013:3-5).

Moreover, Sudaryat (2013) stated, the formal language has the vitality and intellectuality. The vitality language is language that is able to grow up, exist, but un raw in accepting the influenced of another language. The intellectuality talked about how a language is able to apply in science, technology, informatic, and society. Sundanese was standardizing by the vocabulary and spelling. The attempt of Sundanese is constructed dictionary by Roorda (1841). Finally the standardize of Sundanese language that use of Sundanese people is Kamus Umum Basa Sunda by LBSS stated in Sudaryat (2013).

Like another language, Sundanese has sub system of language namely semantic, phonology, phonetic, phonemic, graphemic, graphology, morphology and syntax. It discussed about the lexical and lexicology. The Sundanese language associated to the application especially in oral (speaking and listening) and written (writing and reading) is termed pragmatic. The rule of pragmatic is used to decide the correlation of Sundanese and English consonants with the application of language in a context. Due, the language system includes the pragmatic. The associated of subsystem and the application of language is explained in figure 1.

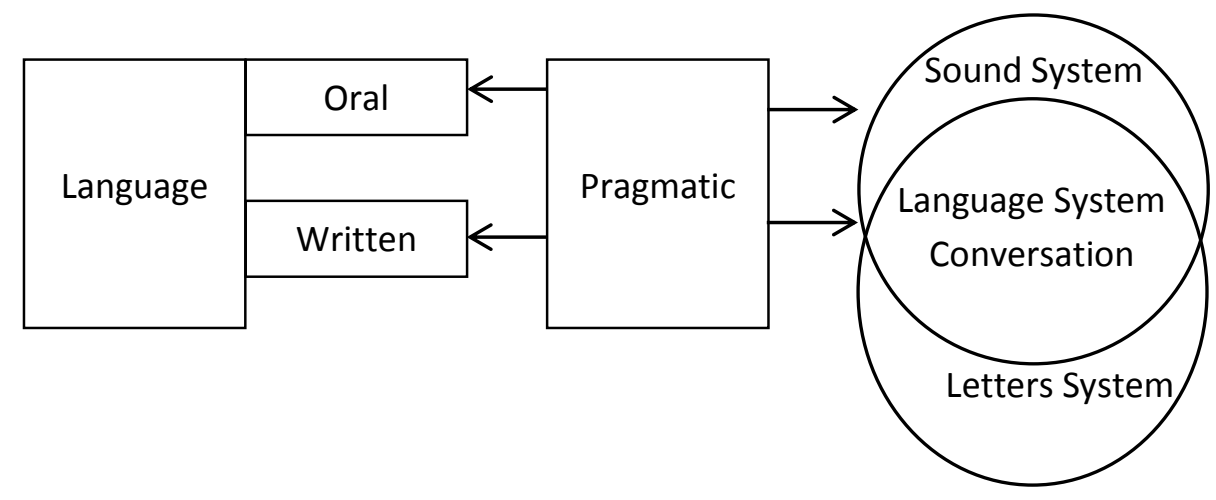

Figure 1 Subsystem of Sundanese Language

The sound of Sundanese language has two senses. They are sora ucap (Parole) and sora pikir (langue) (Sudaryat, 2013).
Sora Ucap is the sound produced by mouth and has a symbol (Phonetic). Sora Pikir is the sound that sound different or similar which differ the meaning of the word (Phoneme). The Sundanese 
phonology has six majors (1) Sounds of language, phoneme, and letters; (2) Speech Organ; (3) the kind of phoneme (vowel and Consonants); (4) The sequence of sound, paragraph, and vocabulary; (5) suprasegmental characteristic; and (6) the kind of sound.
Sawara (Vowel) is the sound that is produced by the air flow of lung without any obstacles (Sudaryat, 2013). In the production of sound, there are three factors effected the quality of sound, there are round-flat the lips, front-back the tongue, and the up-down the tongue. The Sundanese vowels amount of seven.

Table 1 Symbol of Sundanese Vowel

\begin{tabular}{|c|ccccccc|}
\hline Symbol & \multicolumn{7}{|c|}{ Vowel } \\
Graphemics & $\langle\mathrm{a}\rangle$ & $\langle\mathrm{i}\rangle$ & $\langle\mathrm{u}\rangle$ & $\langle\mathrm{e}\rangle$ & $\langle\mathrm{o}\rangle$ & $\langle\mathrm{e}\rangle$ & $\langle\mathrm{eu}\rangle$ \\
Phonemics & $/ \mathrm{a} /$ & $/ \mathrm{i} /$ & $/ \mathrm{u} /$ & $/ \mathrm{E} /$ & $/ \mathrm{o} /$ & $/ \mathrm{e} /$ & $/ \mathrm{eu} /$ \\
Phonetics & {$[\mathrm{a}]$} & {$[\mathrm{i}]$} & {$[\mathrm{u}]$} & {$[\mathrm{E}]$} & {$[\mathrm{o}]$} & {$[\mathrm{\delta}]$} & {$[\mathrm{o}]$} \\
\hline
\end{tabular}

Wianjana is the sound of language constructed by the airflow from the lung with any obstacle (Sudaryat, 2013). The consonants of Sundanese language consist 18, there are: /b/, /c/, /d/, /g/, /h/, /j/, /k/, /l/, /m/, /n/, /ny/, /ng/, /p/, /r/, /s/, $/ \mathrm{t} / \mathrm{h} / \mathrm{w} /$, and $/ \mathrm{y} /$. The consonant of $/ \mathrm{w} /$ and $/ y /$ always called as the semi-vowel or the madya-vowel. Caused of the influenced of the foreigner language, in Sundanese language there are also the /f/, /q/, /v/, /x/, and $/ \mathrm{z} /$. Sundanese has different characteristic with English, especially in their consonant, Sundanese does not have any fricative consonant, it was a foreigner language which applied in that language.
English consonant is the part of phonological object that deeply focused on the sound. According to McCully (2009), the consonant is only sporadically present in my own idiolect, that is, my particular implementation of standard Northern British English, and then only under certain geographical or social circumstances.

Meanwhile, O'Grady, and Dobrovolsky (2005) said, consonant may be voiced and voiceless, are made by the narrow or complete closure in the vocal track. The block or restricted of the airflow is produced as the airflow past the constriction. The consonant is provide in figure 2.7 
Dialectical Literature and Education Journal (DLF $p$-ISSN 2548-6926, e-ISSN 2714-996X

Volume 5, Issue 1, June 2020

https://dlejpancasakti.ac.id/index.php/dlejpancasakti

THE INIERNATIONAL PHONETIC ALPHABET (revised to 2005)

\begin{tabular}{|c|c|c|c|c|c|c|c|c|c|c|c|}
\hline \multirow[b]{2}{*}{ Plouse } & \multirow{2}{*}{$\begin{array}{ll}\text { Bulabial } \\
\mathrm{p} & \mathrm{b}\end{array}$} & Labioiodeetal & \multirow{2}{*}{ Deathat } & \multirow{2}{*}{$\frac{\text { Alveolat }}{\mathrm{t} \mathrm{d}}$} & \multirow{2}{*}{ Postatveotar } & \multirow{2}{*}{ Retroflex } & \multirow{2}{*}{$\begin{array}{l}\text { Palinat } \\
\text { c f }\end{array}$} & \multirow{2}{*}{$\frac{\text { Velar }}{\mathrm{k} \mathrm{g}}$} & \multirow{2}{*}{$\begin{array}{ll}\text { Urulas } \\
\mathrm{q} & \mathrm{G} \\
\end{array}$} & Pharyugeal & \multirow{2}{*}{\begin{tabular}{l|l}
\multicolumn{2}{l}{ Glottal } \\
$?$
\end{tabular}} \\
\hline & & & & & & & & & & & \\
\hline Nonal & $\mathrm{m}$ & $\mathrm{m}]$ & & n & & $\eta$ & $\mathrm{n}$ & 1] & $\mathrm{N}$ & & \\
\hline Irill & B & & & r & & & & & $\mathrm{R}$ & & \\
\hline Top of Flop & & $V^{+}$ & & f & & I & & & & & \\
\hline Fricative & $\phi \beta$ & f $v$ & $\theta \quad \delta$ & S $\mathrm{Z}$ & 3 & s $z$ & ç j & $\mathrm{X} \quad \mathrm{Y}$ & $\chi \quad$ в & $\hbar S$ & h fi \\
\hline $\begin{array}{l}\text { Lateral } \\
\text { ficative } \\
\end{array}$ & & & & 15 & & & & & & & \\
\hline Approximanet & & $v$ & & I & & t & j & पu & & & \\
\hline $\begin{array}{l}\text { Lateral } \\
\text { 2ppraximant }\end{array}$ & & & & 1 & & & $\Lambda$ & L & & & \\
\hline
\end{tabular}

Figure 2 International Phonetic Alphabet

During the same time period that Behaviorism was relevant, (Lado in Geeslin 2014) about the Contrastive Analysis Hypothesis that stated linguistics could predict areas of difficulty for target language learners through a careful comparison of the first language to the target language. It means that the different structure of both language made the difficulty in adapting the language. The difficulty made the error in learning the target language especially in sounds and grammar.

Meanwhile, the first language plays a minimal role in the developing of target language (Geeslin, 2014). It means that the influence of first language strongly effect to the target language. The effect of the first language could not be expected as we thought.

The similar finding by Flowerdew (in Kang and Ginther 2018), concludes that student find difficult to comprehend the unfamiliar accents. They just comprehend of what they knew before especially their mother tongue. It clear that the student would acquire in their accent in learning a target language.

According to Kang and Ginther (2018), the sounds known by the students in their first language or mother tongue would compare to the sound of target language. The main premise was that if a sound was shared by or similar in both languages, then it would be relatively easy to acquire. Kang and Ginther (2018) stated that the problem is if a target language sound were not found in their first language, it would be pronounced differently as their first language. It appears in consonants and vowel features. It means that the student would transform the sound of target language to their first language. Those are the aim of this research conducted. 


\section{METHOD}

This research is conducted in SMA Mutiara Terpadu Palabuhanratu. The school is chosen by the researcher because of the English language development was a priority. The school trains the student to comprehend English fluently. Beside that the researcher observed that the community of the place is variants especially for Sundanese student. The Sundanese student of the school is come from several regions in West Java. They are from Garut, Bandung, and the district of Sukabumi especially Jampang, Surade, Palabuhanratu and other. The researcher took 43 samples from 409 population.

In this research, the researcher used the qualitative research as the method of the research. The research observed analyzed Sundanese language to English consonant pronunciation. In doing the research, the researcher describes the object of the research and explains the phenomenon in the research.

Furthermore, Creswell (2013) stated qualitative research is a means for exploring and understanding the meaning individuals or groups ascribe to a social or human problem. The process of research involves emerging questions and procedures; collecting data in the participants' setting; analyzing the data inductively, building from particulars to general themes; and making interpretations of the meaning of the data. The final written report has a flexible writing structure. From the definition above, this research focused in qualitative research in language sectors, especially in exploring the problem or phenomenon in the language learning.
The data collecting technique of this research used questionnaire, test, and interview. Which are focused on the problem and the aims of the research is gaining information about the analysis of the subject especially Sundanese students' English pronunciation. The questionnaire provided 30 questions of the object of the research that contain the aspect that could helped in gaining information of the samples. Samples just answered the questionnaire by using their behavior or daily activity in learning English. The answers of the questionnaire are strongly agree, agree, uncertain, disagree, and strongly disagree.

This interview providing 10 questions about the object of the research. Samples are free to answer as they behavior, their knowledge and their ability in interviewing. The researcher guides the sample to talk much about the object of the questions.

The test is a process of gaining further information about the samples of their ability in pronouncing an English language. In this test, the researcher uses a test of the sample about their ability in pronouncing English consonants. The passage is provided free and samples have a chance to choose some passage that they want to read. In this process, the researcher records of the samples pronunciation especially in their reading. As a result of the record, researcher analyzes it specifically

Based on the data collecting technique in analyzing Sundanese language to students' English consonant pronunciation, the researcher analyze the data by reading and memoring the important aspect that support of the research which are taken from the questionnaire and the result of students 
test. The reading and memroing step are focused on consonant of students' pronunciation. The next step is classifying the data every part, especially the kind of consonant which is the focused object of the research. The final aspect is describing the data specifically. Every samples are described in answering the problem of the research.

\section{RESULT AND DISCUSSION}

The research has been conducted in one month by spreading questionnaires, testing, and interviewing. In this part, the data of the research will be presented and analyzed specifically. The data was taken from 43 samples of the population in SMA Mutiara Terpadu Palabuhanratu Academic Year 2019/2020. Every samples are described specifically in answering the problem of the research and classifying every part of consonants. Seems like the theory of Geeslin (2014), the first language plays a minimal role in the developing of target language. It means that the influence of first language strongly effect to the target language. The effect of the first language could not be expected as we thought.

\section{(The Main Appearances of Sundanese Language to Student English Consonant Pronunciation)}

According to the result of the test, the consonant ' $f$ ' transformed to ' $p$ ' sound. $94 \%$ from the samples transformed this sound to ' $p$ ' consonant in some word that provided for example 'from' become 'prom, 'forest become 'porest', 'feasting' become 'peasting', etc. $100 \%$ samples are wrong in pronouncing the consonant. They transformed the sound as the letter of its sound for example 'through' become 'trug', 'thick' become 'tik' and even more the sound ' $\theta$ ' banned in a word for example 'length' become 'leng'. 98\% samples pronounced the consonant ' $\int$ ' to
' $s$ ' consonant. for example, the word 'sharp' which is pronounced 'sarp'. $100 \%$ samples pronounced ' $v$ ' consonant to ' $f$ ' or even ' $p$ ' consonant. for example 'vulnerable' to 'pulnerable' or 'fulnerable', 'native' to 'natife' or 'natip', 'average' to 'aperage' or 'aferage', 'exclusively' to 'exclusipely', or 'exclusifely', 'leaves' to 'leafs' or 'leaps', 'having' to 'haping' or 'hafing', 'very' to 'fery' or 'pery', and 'variety' to 'pariety' or 'fariety'. $100 \%$ samples pronounced ' $\partial$ ' transformed to another consonant. The example are 'the' to 'de', 'northern' to 'nordern', 'than', to 'dan', 'although' to 'aldough' or 'altogh', 'though' to 'togh', 'mother' to 'moder', 'they' to 'dey', and 'themselves' to 'demselpes'. 100\% samples pronounced the ' $z$ ' to another consonant. $100 \%$ sample pronounced is (iz) to is(is) , 'sized' to 'sijed' or 'sised', has (haz) to 'has', 'ears' (ioz) to 'ears' (irs), 'eyes' (aiz) to 'eyes' (ais), 'leaves' (li:vz) to 'leaves' (li:fs), and 'as' (az) to 'as' (az). 98\% samples pronounced 'awakens' (o'werkanz) to 'awakens' (a 'werkans). $100 \%$ samples pronounced ' 3 ' to ' $\mathrm{s}$ ' sound example 'occasionally' (a'kerznali) to 'occasionally' (a'keIsinali). $100 \%$ samples pronounced ' $y$ ' to ' $c$ ' sound, for example 'search' to 'searc', 'pouch' to 'pouc', and 'wich' to 'wic'. 96\% samples pronounced 'ds' to another consonant. Majority, many samples transformed the consonant to ' $g$ ' consonant., for example 'large' (la:ds) to 'large' (large), and 'foliage' ('favlindz) to 'foliage' ('favlinge). 
Many of samples stated the reason of transforming a consonant caused of the period of time in learning English. They learned English above 3 or 4 years with the comprehensively learning in senior high school. Based to the result, $96 \%$ stated that. $100 \%$ samples assumed that Sundanese was influence to their English especially pronunciation. They claimed the different both of language impacted their pronunciation especially in pronouncing fricative and affricative sound. They claimed that their habitual language in speaking Sundanese was influence them especially in accent and pronouncing a sound. the Sundanese accent was influence to their pronunciation especially in pronouncing the last double consonant in a word, for example around because of there was no double last consonant in Sundanese, they pronounce only first consonant like 'arroun'. 100\% samples claimed that they do not really know about pronouncing a sound in another form for example is which is pronounce as ' $i z$ ' or ' $o f$ ' is pronounced as ' $o v$ '. They claimed that they do not really know about this phenomenon. $98 \%$ perceived that they able to pronounce English sound well. Because of their perception, they stated able in questionnaire especially in differing an English sound without any transformation. They claimed the entire time they learned English, they felt correct in pronunciation as they perception.

\section{(Fricative English Sounds Pronounced by Sundanese Students)}

\footnotetext{
Sundanese influenced to students English with transformed ' $a$ ' undefined sounds to the similar sound of
}

it. Most of sample transformed an English consonant like ' $\delta$ ' to ' $d$ ', ' ' ' to ' $s$ ', ' $f$ ' to ' $p$ ', ' $v$ ' to ' $p$ ', and ' $z$ ' to ' $s$ '. Besides that, many of sounds pronounced as their letters especially ' $d j$ ' to ' $g$ ', ' $\delta$ ' to ' $t$ ', ' $t y$ ' to ' $c$ ', ' $\theta$ ' to ' $t$ ', etc.

The transformation of this consonants appeared because of the different of both of language. The main of consonants transformation are fricative and affricative which are the undefined consonant in Sundanese language. Those sound are ' $v$ ', 'f', 'd $d$ ', 'ty', ' 3 ', ' $\int$ ', ' $\theta$ ', and ' $\delta$ ' sound. This result was suitable with Geeslin (2014) statement about the first language plays a minimal role in the developing of target language. it means that Sundanese plays rule of English consonant pronunciation.

\section{(The New Variant of Sundanese Student English Consonant Sounds)}

Sundanese influences in creating a new variant sound of English, especially in generalizing the sound. It appeared in pronouncing the consonant of English. As (Kang and Ginther, 2018:286), the sounds known by the students in their first language or mother tongue would compare to the sound of target language. The main premise was that if a sound was shared by or similar in both language, then it would be relatively easy to acquire. (Kang and Ginther, 2018:284-285) stated that the problem is if a target language sound were not found in their first language, it would be pronounced differently as their first language. The new variant in generalize ng the English sound provide at table 2. 
Table 2

\section{The New Variant of Consonant}

\begin{tabular}{|c|c|}
\hline Sound $\mathbf{1}$ & Sound $\mathbf{2}$ \\
\hline$V$ & $f / p$ \\
$d 3$ & $G$ \\
\hline & $D / T$ \\
$\int$ & $S$ \\
$Z$ & $J / s$ \\
$t$ & $c / k$ \\
3 & $S$ \\
$F$ & $P$ \\
$\theta$ & $T$ \\
$X$ & $s$ \\
\hline
\end{tabular}

\section{CONCLUSION}

This research will useful practically and theoretically. The object of research about analysis of a language to a target language will give new knowledge of a foreigner language learning and also give a new solution in solving the problem that always happen in that case. Actually, for the learner and a teacher could predict the error in learning a target language process.

Based on the findings and discussion, the conclusion of this research could be drawn as follows. The main Sundanese language aspect

appearances to their consonant pronunciation are the accent of Sundanese and the unknown sounds of English in Sundanese. Many samples of this research are Sundanese who got difficulty in pronunciation especially in pronouncing unknown sounds. Majority, samples were confused in adapting English sound of their tongue because of their habitual language factors. Samples got difficulty in pronouncing the English consonant sound especially the different sound of English and Sundanese. They thought that they have lack of knowledge and get difficulty in pronouncing the sounds. It is difficult for them to pronounce English especially in pronouncing ' $r$ ' consonant which pronounced clearly, stressing, intonation, and the articulation of English. The unknown consonants of English made them transforming those sound to similar sound in Sundanese. Beside that the transforming English consonant to Sundanese consonant which do not defined in Sundanese language especially [f], [v], [z], and other. 
Dialectical Literature and Education Journal (DLE p-ISSN 2548-6926, e-ISSN 2714-996X

\section{REFERENCES}

Creswell, J. W. (2014). Research Design:

Qualitative, Quantitative, and Mixed Methods Approaches. University of Nebraska-Lincoln California: SAGE.

Gay, Geoffrey, \& Airasian. (2012). Educational Research Competencies for Analysis and Applications. USA: PEARSON

Geeslin, K. L. (2014). Sociolinguistics and Second Language Acquisition. New York: Routledge

Kang, O. \& Ginther, A. (2018). Assessment in Second language Pronunciation. New York: Routledge

McCully, C. (2009). The Sound Structure of English. Netherland: Rijksuniversiteit Groningen

O'Grady, W. and Dobrovolsky, M. (2005). Contemporary Linguistics an Introduction. University of California: Longman.

Sudaryat, P. and Yudbrata. (2013). Tata Basa Sunda Kiwari. Bandung: Yrama Widya

Suriamiharja, A. (1981). Pusat Pembinaan dan Pengembangan Bahasa: Geografi Dialek Sunda. Jakarta: Depdikbud. 